\title{
NATURAL COMPOUNDS FROM DJIBOUTIAN MEDICINAL PLANTS AS INHIBITORS OF COVID- 19 BY IN SILICO INVESTIGATIONS
}

\author{
ABDIRAHMAN ELMI'* S. AL-JAWAD SAYEM², MOHAMED AHMED1 ${ }^{1}$, FATOUMA ABDOUL-LATIF1 \\ ${ }^{1}$ Medicinal Research Institute, Centre d'Etudes et de Recherche de Djibouti, IRM-CERD, Route de l'Aéroport, Djibouti, ${ }^{2}$ International \\ Islamic University Chittagong, Departement of Pharmacy, Bangladesh \\ Email: abelfourreh@hotmail.com \\ Received: 25 Mar 2020, Revised and Accepted: 22 May 2020
}

\begin{abstract}
Objective: The new coronavirus type SARS-Cov 2 (severe acute respiratory syndrome), which appeared in autumn 2019 in China, became a global pandemic in a few months. In this work, we looked for the potential anti SARS-Cov 2 of the compounds isolated from three Djiboutian medicinal plants, namely Acacia seyal, Cymbopogon commutatus, and Indigofera caerulea.

Methods: We carried out a molecular docking with nine biomolecules, $\beta$-Sitosterol, Quercetin, Catechin, Lupeol, Rutin, Kaempferol, Gallic acid, Piperitone and Limonene on three target sites which are SARS-CoV-2 main protease (Mp), SARS-CoV-2 receptor-binding domain (RBD) and human furin protease. These targets are chosen because of their role in the process of penetration of the virus into human cells and its multiplication. Moreover, the predictions of pharmacokinetic parameters as well as toxicological properties have been determined using an online bioinformatics tool named SwissADME and AdmetSAR respectively.
\end{abstract}

Results: The phenolic compounds have a very good affinity on these three target sites with binding energies of up to-9.098 kcal/mol for rutin on SARS-CoV-2 Mp, much better than the two reference drugs hydroxychloroquine $(-5.816 \mathrm{kcal} / \mathrm{mol})$ and remdesivir $(-7.194 \mathrm{kcal} / \mathrm{mol})$. Except for $\beta$ Sitosterol, the tested biomolecules have weak toxicity.

Conclusion: These natural compounds can be used against covid 19 pending In vitro and In vivo evaluations.

Keywords: Biomolecules, Djibouti medicinal plant, Anticovid 19 and molecular docking

(C) 2020 The Authors. Published by Innovare Academic Sciences Pvt Ltd. This is an open access article under the CC BY license (http://creativecommons.org/licenses/by/4.0/) DOI: http://dx.doi.org/10.22159/ijcpr.2020v12i4.39051. Journal homepage: https://innovareacademics.in/journals/index.php/ijcpr

\section{INTRODUCTION}

Coronaviruses are viral particles, and their outer envelope, which has spicules, made up of the surface protein $S$, gives the characteristic crown appearance visible by electron microscopy [1]. These viruses affect both humans and animals, and in some cases cause serious infections of the respiratory systems.

The new coronavirus, abbreviated covid 19, appeared in autumn 2019 in China and has since spread to the rest of the world. In the absence of vaccination, treatments are tried to reduce the viral load and the effects of the induced symptoms. As part of this, a European program called discovery is testing four molecules against the coronavirus, namely remdesivir, lopinavir, ritonavir, and hydroxylchloroquine [2].

Everywhere the search for effective therapeutic molecules is intensifying and, due to the urgency of the situation, evaluations by computer simulation can save time. The interaction between these molecules and specific targets of the coronavirus is measured.

Three targets are favored in the search for effective treatments. They are Furin, a kind of proprotein convertases, and receptor binding domain of SARS-CoV-2 spike protein to prevent viral entry and SARS-CoV-2 main protease essential of viral replication [3, 4].

Plants have been very present in the treatment of human pathologies for thousands of years. Medicines or compounds very effective of vegetable origin already exist on International market: the isolated maprouneacin of the Maprounnea africana is used like an antidiabetic agent, Taxol ${ }^{\circledR}$ (paclitaxel resulting from Breviflora taxus) is used like notorious antitumor or artemisinin (Artemisia annua) is used as an effective antimalarial agent against all resistant strains of Plasmodium [5].

Djibouti, East Africa country, has an arid and desert climate. The average rainfall is low, around $250 \mathrm{~mm}$ [6]. However, more than 800 species are listed and their adaptation under these difficult conditions may be of interest for their medicinal uses.

As part of the promotion of Djiboutian medicinal plants, various bioactive compounds have been isolated for their antimicrobial and anticancer effects. In this present study, we will evaluate the potential anticovid therapeutics of these biomolecules through molecular simulation on the targets SARSCoV-2 RBD, SARS-CoV-2 main protease, and human furin protease. We will determine the energies of molecule-target virus interaction, ADME (absorption, distribution, metabolism, and excretion) as well as possible toxicities generated from these molecules.

\section{MATERIALS AND METHODS}

Study compound

The nine compounds tested are $\beta$-Sitosterol, Quercetin, Catechin, Lupeol, Rutin, Kaempferol, Gallic acid, Piperitone, and Limonene (fig. 1). They were isolated from three Djiboutian medicinal plants: Acacia seyal, Cymbopogon commutatus, and Indigofera caerulea (Picture 1). The extractions and isolations of these compounds are described in our previous publications [7-9].

Two drugs against covid are used for comparison: Remdesivir and Hydrochloroquine (fig. 1).

\section{In silico investigation}

Proteins and chemical compounds studied in this investigation

Three proteins were selected for the purpose of this study; 1 . SARSCoV-2 main protease (PDB ID: 5R84) [10] (Fearon et al. 2020), 2. Human furin protease (PDB ID: 5MIM) [11], and 3. SARS-CoV-2 receptor-binding domain (PDB ID: 6VW1) [12]. Nine compounds were also selected; 1 . $\beta$-Sitosterol (PubChem CID 222284), 2. Quercetin (PubChem CID 5280343), 3. Catechin (PubChem CID 9064), 4. Lupeol (PubChem CID 259846), 5. Rutin (PubChem CID 5280805), 6. 
Kaempferol (PubChem CID 5280863), 7. Gallic acid (PubChem CID 370), 8. piperitone (PubChem CID 6987), 9. Limonene (PubChem CID
22311), along with two reference drugs remdesivir (PubChem CID 121304016), and hydroxychloroquine (PubChem CID 3652).

\section{Graphical abstract}

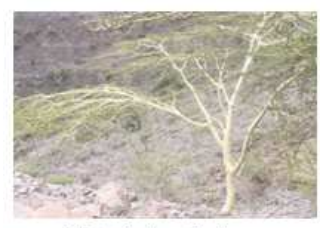

\section{Medicinal plant}

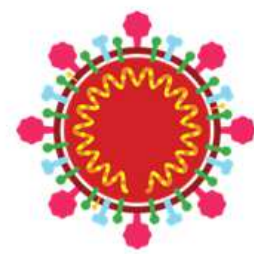

SARS- Cov 2
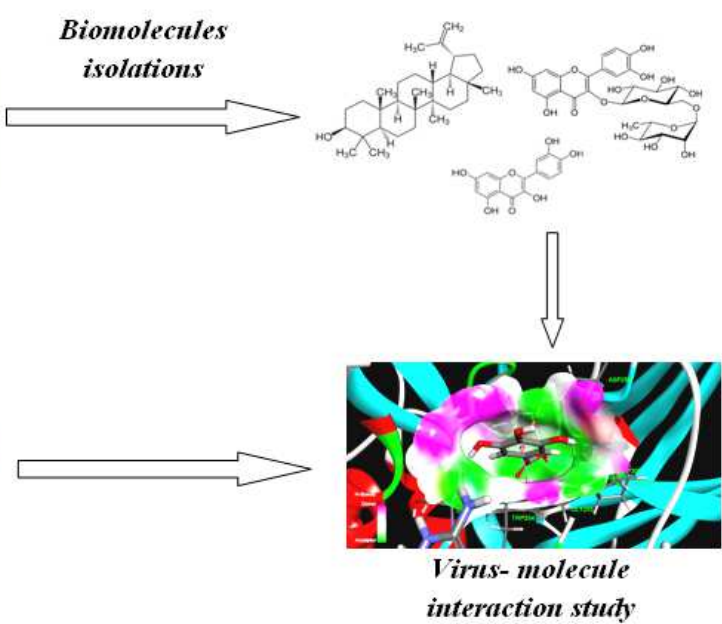
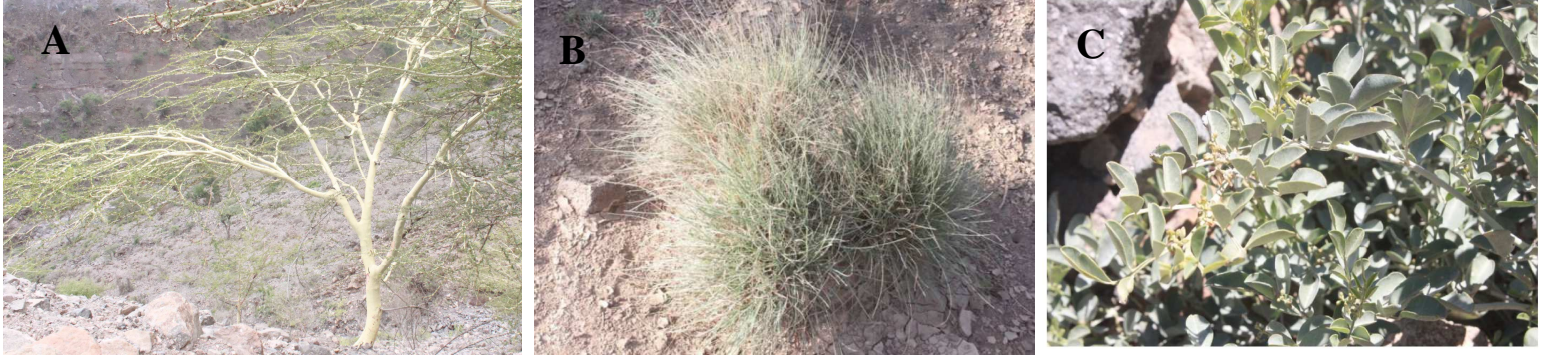

Picture 1: (A) Acacia seyal, DAY, Tadjourah district (North of Djibouti); (B) Cymbopogon commutatus, BARA, Ali sabieh district (Center of Djibouti) and (C) Indigofera caerulea, ABAIDO, Dikhil district (South West of Djibouti)<smiles>O=C1c2cc(O)cc(O)c2CC(c2ccc(O)c(O)c2)C1O</smiles>

Quercetine<smiles>Oc1cc(O)c2c(c1)OC(c1ccc(O)c(O)c1)C(O)C2</smiles><smiles>O=C1c2c(O)cc(O)cc2OC(c2ccc(O)cc2)C1O</smiles>

Kaempferol
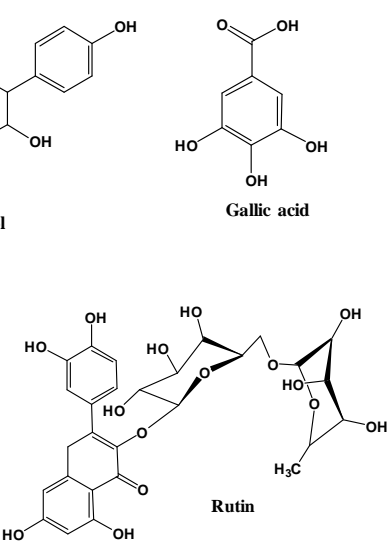

Lupeol

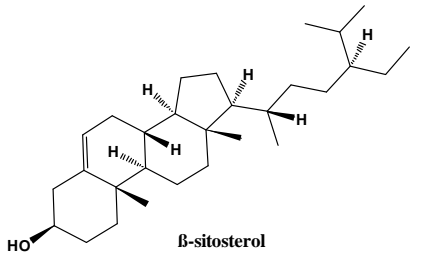<smiles>CCN(CCO)CCCC(C)Nc1ccnc2cc(Cl)ccc12</smiles><smiles>CC1=CC(=O)C(C(C)C)CC1</smiles>

(R)-Piperitone
Limonene<smiles>C=C(C)[C@H]1CC=C(C)CC1</smiles>

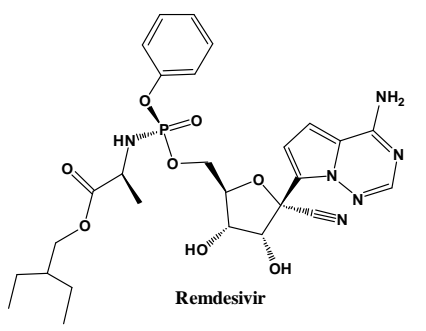

Fig. 1: Molecular structure of selected compounds and drug references 


\section{Molecular docking: preparation of ligand}

The chemical structures of eleven selected compounds were obtained from PubChem an online repository of chemical compounds (https://pubchem.ncbi.nlm.nih.gov/). The structures were obtained in 2D SDF format. A bioinformatics tool called LigPrep was used to performing ligand preparation. LigPrep is set in Schrödinger suite-Maestro ( $v$ 11.1). The following parameters were taken into consideration during this job: the structure was set as project table, the force field was set at OPLS3, the target $\mathrm{pH}$ was $7.0 \pm 2.0$ using Epik and the output format was Maestro.

\section{Molecular docking: preparation of protein}

The desire proteins were taken from Protein Data Bank (PDB) an online database (https://www.rcsb.org/). The three-dimensional protein structures were downloaded in pdb format [13]. The Resolution was $1.83 \AA, 1.9 \AA$, and $2.68 \AA$ of selected proteins with PDB ID: 5R84, 5MIM, and 5R84, respectively. Preprocessing, optimization, and minimization were done by using the Protein Preparation Wizard for preparing the proteins [14]. This wizard is also included in Schrödinger suite-Maestro ( $\mathrm{v}$ 11.1). The following parameters were used in this job; the structures were optimized at $\mathrm{pH} 7.0$, remove waters with less than $3 \mathrm{H}$-bond to non-waters, and minimized the proteins using OPLS3 force field. Then generate the receptor grid by using PockDrug an online tool for selecting the best docking site [15].

\section{Molecular docking: glide molecular docking}

The molecular docking was performed to understand the possible mechanism of the selected compound comparing with two reference drugs against the receptors associate with COVID-19 and human. The docking was completed by using the Ligand Docking tool attaches in Schrödinger suite-Maestro ( $v$ 11.1). Then the spreadsheet and 2d interaction fig. were collected for further study. Discovery Studio (v 4.1) software was used for more understanding via $3 \mathrm{~d}$ visualization [16].

\section{Prediction of the pharmacokinetic parameter (ADME)}

Several pharmacokinetic properties such as absorption, distribution, metabolism, excretion (ADME) are important to developing a drug. These following properties are investigated by SwissADME, an online tool to determine various biochemical properties (http://www.swissadme.ch/) [17]. Some parameters were determined for evaluating the compounds from the SwissADME database based on the Lipinski's and Veber's Rules [18]. The following parameters were molecular weight, hydrogen bond acceptor, hydrogen bond donor, $\log \mathrm{P}$ value, Lipinski's Violations value, number of the rotatable bond (NRB), and topological polar surface area (TPSA).

\section{Prediction of toxicological properties}

Toxicological determination is the most prime considerations in case of the development of new drugs. An online bioinformatics tool named Admet SAR was used to evaluating the toxicological properties of desire compounds [19]. The following parameters were counted in this study, such as rat acute toxicity, acute oral toxicity, ames toxicity, and carcinogenic properties.

\section{RESULTS AND DISCUSSION}

Molecular docking of nine biomolecules and two reference drugs is carried out at three target sites: SARS-CoV-2 main protease, SARS$\mathrm{CoV}-2$ receptor binding domain, and human furin protease. Among the different types of interaction between the therapeutic molecule and the targeted active site, the hydrogen bond established with the residues of the active site is critical [20]. The affinity of this bond is evaluated using binding energy $(\mathrm{Kcal} / \mathrm{mol})$. The lower energy corresponds the better affinity between the two entities (target site and therapeutic molecule). The best target site is SARS-CoV-2 Mp, where five compounds (45\%) have binding energy (BE) $\leq-7$ $\mathrm{kcal} / \mathrm{mol}$ (table 1). The rank of each ligand in terms of the least BE among ligands is also provided as fellowing:

SARS-CoV-2 main protease: rutin $>$ Catechin $>$ kaempferol $>$ remdesivir $>$ quercetin $>$ hydroxychloroquine $>$ piperitone $>$ gallic acid $>$ limonene $>\beta$-Sitosterol $>$ lupeol;

SARS-CoV-2 receptor binding domain: remdesivir $>$ rutin $>$ Kaempferol $>$ Catechin $>$ Quercetin $>$ piperitone $>$ gallic acid $>$ hydroxylchloroquine $>$ limonene $>$ lupeol $>\beta$-Sitosterol; human furin protease: quercetin $>$ catechin $>$ rutin $>$ gallic acid $>$ kaempferol $>$ remdesivir $>$ hydroxychloroquine $>$ piperitone $>\beta$-sitosterol $>$ lupeol $>$ limonene.

We note that the five phenolic compounds have a better BE than the terpene compounds, whatever the active site (table 1). At the active site SARS-CoV- $2 \mathrm{Mp}$, rutin $(\mathrm{BE}=-9.098 \mathrm{kcal} / \mathrm{mol})$, catechin $(\mathrm{BE}=-7.677 \mathrm{kcal} / \mathrm{mol}$ ) and kaempferol $(\mathrm{BE}=-7.215 \mathrm{kcal} / \mathrm{mol})$ have a better binding energy than the reference Remdesivir ( $\mathrm{BE}=-7.194$ $\mathrm{kcal} / \mathrm{mol}$ ) and Hydroxychloroquine (BE $=-5.816 \mathrm{kcal} / \mathrm{mol}$ ). As far as to the human furin protease target, five phenolic compounds (yellow in table 1) require less energy to bind than the two-drug references. Quercetin showed very promising anticovid effects in vivo tests with an $\mathrm{IC}_{50}$ of $73 \mu \mathrm{M}$ against SARS-Cov 3CL(pro) [21] and $8.6 \mu \mathrm{M}$ against SARS-Cov PL(pro) [22]. Also, several polyphenols compounds have been reported to show a good inhibition against SARS-Cov on 3CL protease targeted due to their hydrophobic aromatic rings and hydrophilic hydroxyl groups [23, 24]. In this present study, we show that there are other interesting targets.

Table 1: Molecular docking of the selected compound with target protein called SARS-CoV-2 main protease (Mp), SARS-CoV-2 receptorbinding domain (RBD) and human furin protease

\begin{tabular}{|c|c|c|c|c|c|c|c|c|c|}
\hline \multicolumn{4}{|c|}{ SARS-CoV-2 Mp } & \multicolumn{2}{|c|}{ SARS-CoV-2 RBD } & \multicolumn{4}{|c|}{ human furin protease } \\
\hline Compound & BE (kcal/mol) & $\begin{array}{l}\text { Glide } \\
\text { Emodel }\end{array}$ & $\begin{array}{l}\text { Glide } \\
\text { Energy }\end{array}$ & $\begin{array}{l}\text { BE } \\
\text { (kcal/mol) }\end{array}$ & $\begin{array}{l}\text { Glide } \\
\text { Emodel }\end{array}$ & $\begin{array}{l}\text { Glide } \\
\text { Energy }\end{array}$ & $\begin{array}{l}\text { BE } \\
\text { (kcal/mol) }\end{array}$ & $\begin{array}{l}\text { Glide } \\
\text { Emodel }\end{array}$ & $\begin{array}{l}\text { Glide } \\
\text { Energy }\end{array}$ \\
\hline$\beta$ Sitosterol & -3.646 & -35.362 & -29.807 & -- & --- & --- & -3.148 & -36.074 & -30.661 \\
\hline Quercetin & -7.169 & -63.742 & -46.679 & -6.308 & -56.413 & -41.346 & -5.988 & -49.649 & -37.044 \\
\hline Catechin & -7.677 & -69.744 & -48.004 & -6.470 & -58.673 & -43.239 & -5.856 & -56.369 & -41.751 \\
\hline Lupeol & -3.079 & -28.121 & -24.988 & -2.952 & -30.678 & -26.349 & -2.777 & -27.695 & -23.697 \\
\hline Rutin & -9.098 & -101.463 & -71.94 & -7.601 & -88.545 & -67.123 & -5.745 & -77.014 & -57.839 \\
\hline Kaempferol & -7.215 & -59.056 & -42.910 & -6.743 & -56.693 & -41.205 & -5.624 & -45.854 & -33.642 \\
\hline Gallic Acid & -5.441 & -43.604 & -32.518 & -5.767 & -42.971 & -32.428 & -5.732 & -45.735 & -33.766 \\
\hline Piperitone & -5.670 & -28.637 & -21.622 & -5.937 & -30.566 & -22.562 & -3.544 & -20.472 & -16.342 \\
\hline Limonene & -5.234 & -23.826 & -18.247 & -4.218 & -20.981 & -16.712 & -2.700 & -16.444 & -14.181 \\
\hline Remdesivir* & -7.194 & -7.713 & -57.238 & -7.851 & -88.041 & -65.536 & -5.544 & -68.253 & -53.984 \\
\hline Hydroxychloroquine* & -5.816 & -54.822 & -42.432 & -4.828 & -44.138 & -37.550 & -4.277 & -44.157 & -37.096 \\
\hline
\end{tabular}

*Remdesivir and Hydroxychloroquine used as references. Blue: Docking Score Is greater than Hydroxychloroquine; Yellow: Docking Score Is greater than Remdesivir and Hydroxychloroquine.

The 2-D visualization of the compounds for each target having a BE lower than at least one of two references, blue in table 1 , is represented (fig. 2) and in 3D for those having a BE lower than the two references, yellow in table 1, (fig. 3). The docking analysis 
showed that Quercetin forms H-bonds with SARS-CoV-2 Mp amino acids Glu 166, Hie 164, Hie 163, Gln 189; with SARS-CoV-2 RBD amino acids Ile 358, Asn 388, and HF protease amino acids Glu 236, Leu 227, Ash 264, and Glh 257 (fig. 2A/B/C). Catechin forms $\mathrm{H}$ bonds with SARS-CoV-2 Mp amino acids Glu 166, Hie 164; with SARS-CoV-2 RBD amino acids Ser 359, Asn 331, Cys 361, Ile 332, and HF protease amino acids Asp 306, Pro 256, and Asp 258 (fig. 2A/B/C). Rutin forms H-bonds with SARS-CoV-2 Mp amino acids Glu 166, Leu 141, Thr 26; with SARS-CoV-2 RBD amino acids Asn 388, Asp 389, Ala 363, Cys 361, Ser 359, Ile 332, and Asn 331 and with HF protease amino acids Asp 153, Leu 227, Asn 295, Asp 258, and Gly 255 (fig. 2A/B/C). Kaempferol forms H-bonds with SARS-CoV-2 Mp amino acids Glu 166, Gln 189, Hie 164; with SARS-CoV-2 RBD amino acids Ile 358, Asn 388, and HF protease amino acids Leu 227, Glh 257, Ash 264, and Glu 236 (fig. 2A/B/C). Gallic acid forms H-bonds with SARS-CoV-2 RBD amino acids Ser 359, Tyr 365, Leu 390, and HF protease amino acids Ser 253, Pro 256, and Asp 306 (fig. 2B/C). And finally, Piperitone forms only unfavorable interaction with SARS-CoV-2 RBD amino acids Phe 392 (fig. 2B).

Rutin has the largest hydrogen bond with $15 \mathrm{H}$-bonds on all three targets followed by quercetin (10 H-bonds), catechin ( $9 \mathrm{H}$-bonds), kaempferol ( 9 H-bonds) and gallic acid (6 H-bonds). This high number of rutin binding is linked to its hydroxyl group richness (10 $\mathrm{OH})$. Glycosylated phenolics have better docking than their corresponding aglucone [25].
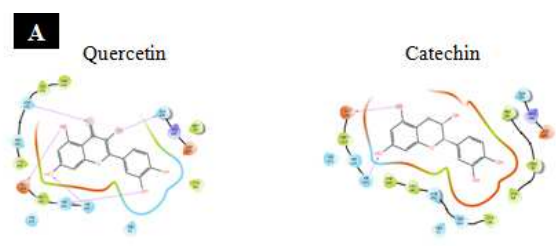

B Quercetin
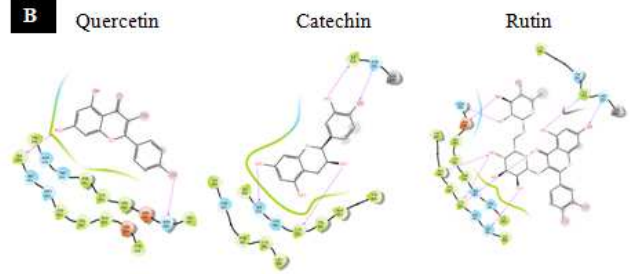

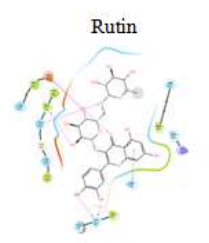

Kaempferol
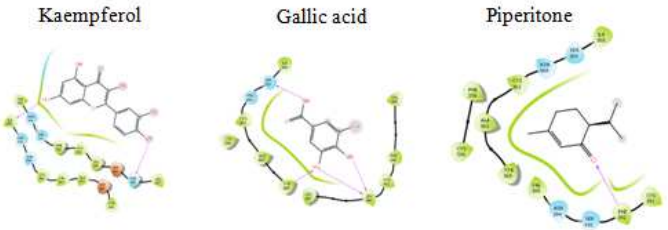

c
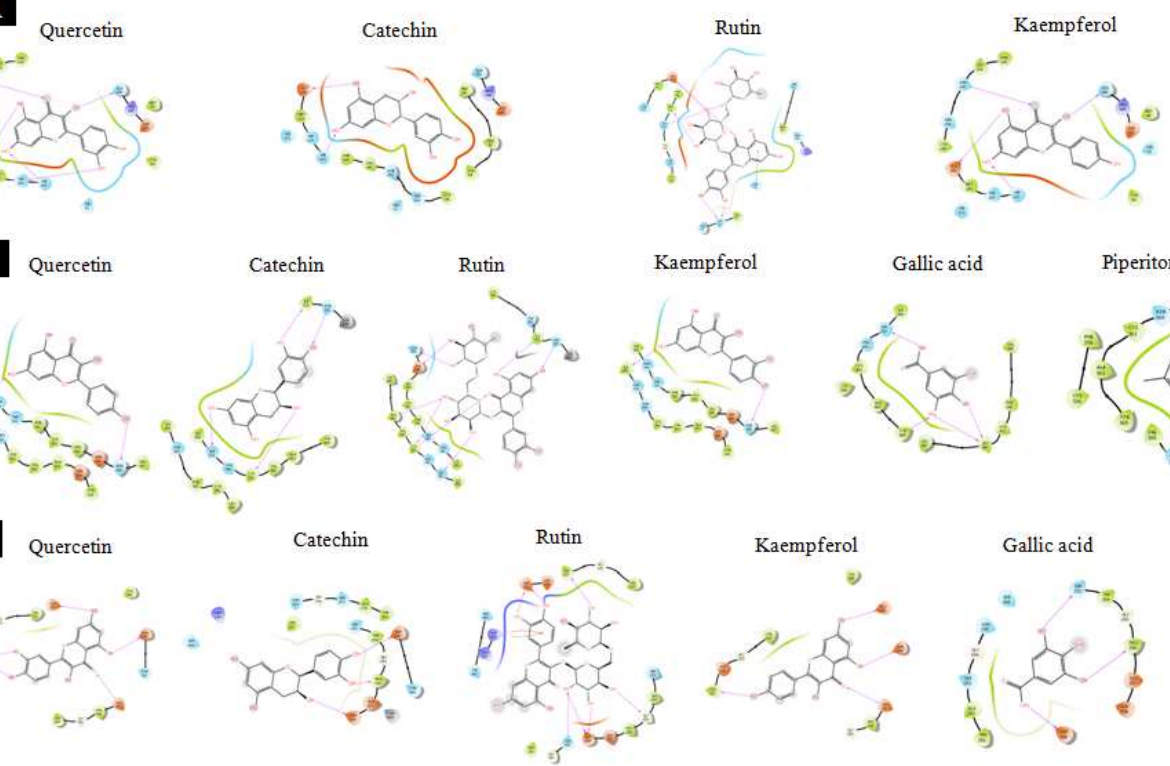

Fig. 2: 2D visualization of molecular interaction of SARS-CoV-2 main protease (A), SARS-CoV-2 receptor binding domain (B) and human furin protease (C) with the biomolecules having at least better binding energy than one reference drug (hydroxychloroquine or/and Remdesivir)

A

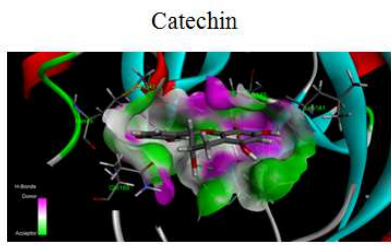

B

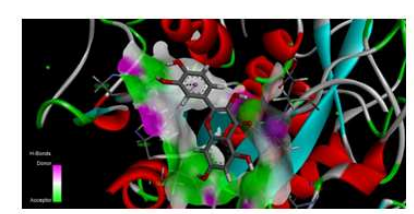

Rutin

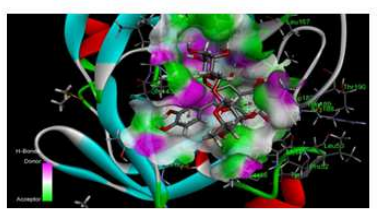

Catechin

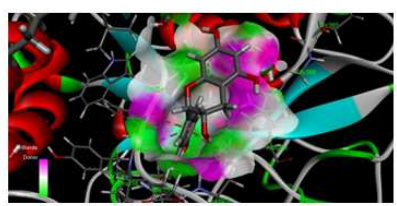

Kaempferol

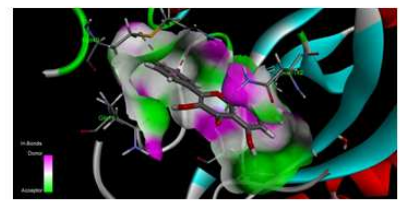

Rutin

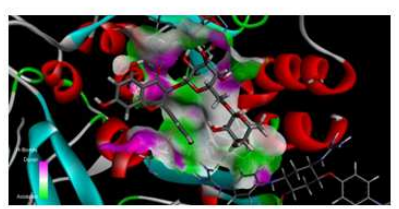

Kaempferol

Gallic acid
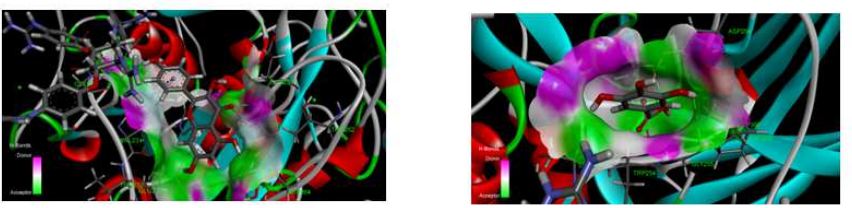

Fig. 3: 3D visualization of docking analysis of SARS-CoV-2 main protease (A) and human furin protease (B) binding with the biomolecules having better binding energy than the two drug reference (hydroxychloroquine and Remdesivir) 
Furthermore, knowledge of the pharmacokinetic parameters and the degree of toxicity of the candidate compounds to become a drug is crucial. Computer simulation makes it possible to rule out molecules that would not respond to the above parameters at an early stage. First, we used Swiss ADME to calculate ADME (absorption, distribution, metabolism, excoriation) according to Lipinski's and Veber's Rules. Only rutin and remdesivir have values beyond those defined by Lipinski's and Veber's Rules (table 2). This is one of the reasons that remdesivir is not currently available for oral administration. Since the beginning of May 2020 the American administration has given its authorization for the use of this drug against covid 19. However, its mode of intravenous administration does not facilitate rapid large-scale production and often requires hospitalization of the patient [26].

On the other hand, the admetSAR1 online server was used to determine toxicological properties. The studied compounds are noncarcinogenic (table 3 ). In acute oral toxicity, $\beta$-Sitosterol is in category I (with LD50 $\leq 50 \mathrm{mg} / \mathrm{kg}$ ), quercetin and kaempferol in category II $(50 \mathrm{mg} / \mathrm{kg}>\mathrm{LD} 50<500 \mathrm{mg} / \mathrm{kg}$ ), Lupeol, rutin, gallic acid, piperitone and limonene in category III $(500 \mathrm{mg} / \mathrm{kg}>\mathrm{LD} 50<$ $5000 \mathrm{mg} / \mathrm{kg}$ ) and finally catechine in category IV (LD50 values > $5000 \mathrm{mg} / \mathrm{kg}$ ). Except for $\beta$-sitosterol, none of the compounds displayed a risk of ames toxicity, carcinogenicity, acute oral toxicity, and rat acute toxicity (table 3 ).

Table 2: Physicochemical properties of the selected compounds for good oral bioavailability by SwisADME

\begin{tabular}{|c|c|c|c|c|c|c|c|}
\hline \multirow[t]{2}{*}{ Compounds } & \multicolumn{4}{|c|}{ Lipinski rules } & \multirow{2}{*}{$\begin{array}{l}\text { Lipinski's } \\
\text { Violations } \\
\leq 1 \\
\end{array}$} & \multicolumn{2}{|c|}{ Veber rules } \\
\hline & $\begin{array}{l}\mathrm{MW}(\mathrm{g} / \mathrm{mol}) \\
<500\end{array}$ & $\begin{array}{l}\text { HBA } \\
<10 \\
\end{array}$ & $\begin{array}{l}\text { HBD } \\
<5 \\
\end{array}$ & $\begin{array}{l}\log P \\
\leq 5\end{array}$ & & $\begin{array}{l}\mathrm{nRB} \\
\leq 10 \\
\end{array}$ & $\begin{array}{l}\text { TPSA } \\
\leq 140 \\
\end{array}$ \\
\hline Beta Sitosterol & 414.71 & 1 & 1 & 9.34 & 1 & 6 & 20.23 \\
\hline Quercetin & 302.24 & 7 & 1 & 1.54 & 0 & 1 & 131.36 \\
\hline Catechin & 290.27 & 6 & 5 & 0.36 & 0 & 1 & 110.38 \\
\hline Lupeol & 426.72 & 1 & 1 & 9.87 & 1 & 1 & 20.23 \\
\hline Rutin & 610.52 & 16 & 10 & -0.33 & 3 & 6 & 269.43 \\
\hline Kaempferol & 286.24 & 6 & 4 & 1.90 & 0 & 1 & 111.13 \\
\hline Gallic Acid & 170.12 & 5 & 4 & 0.70 & 0 & 1 & 97.99 \\
\hline Piperitone & 152.23 & 1 & 0 & 2.85 & 0 & 1 & 17.07 \\
\hline Limonene & 136.23 & 0 & 0 & 4.57 & 0 & 1 & 0.00 \\
\hline Remdesivir & 602.58 & 12 & 4 & 1.91 & 2 & 14 & 213.36 \\
\hline Hydroxychloroquine & 335.87 & 3 & 2 & 3.58 & 0 & 9 & 48.39 \\
\hline
\end{tabular}

$M W$ : molecular weight, $H B A$ : hydrogen bond acceptor, $H B D$ : hydrogen bond donor, $\log P$ : lipophilicity, $A M R$ : molar refractivity; Ro5V-Rule of five violation.

Table 3: Toxicological properties of the selected compounds BY admet SAR

\begin{tabular}{lllll}
\hline Compound & Parameters & & & \\
\cline { 2 - 5 } & Ames toxicity & Carcinogens & Acute oral toxicity & Rat acute toxicity \\
\hline Beta-Sitosterol & NAT & NC & I & 2.6561 \\
Quercetin & NAT & NC & II & 3.0200 \\
Catechin & NAT & NC & IV & 1.8700 \\
Lupeol & NAT & NC & III & 3.3838 \\
Rutin & NAT & NC & III & 2.4984 \\
Kaempferol & NAT & NC & II & 3.0825 \\
Gallic Acid & NAT & NC & III & 1.8670 \\
Piperitone & NAT & NC & III & 1.8246 \\
Limonene & NAT & NC & III & 1.4819 \\
Remdesivir & NAT & NC & III & 2.7169 \\
Hydroxychloroquine & NT & NC & III & 2.6348 \\
\hline
\end{tabular}

NAT: Non-Ames toxic; NC: Non-carcinogenic; (Category-I compound with LD50 $\leq 50 \mathrm{mg} / \mathrm{kg}$. Category II compounds with LD50 values $>50 \mathrm{mg} / \mathrm{kg}$ and $<500 \mathrm{mg} / \mathrm{kg}$. Category III compounds with LD50 values $>500 \mathrm{mg} / \mathrm{kg}$ and $<5000 \mathrm{mg} / \mathrm{kg}$. Category IV compounds with LD50 values $>5000$ $\mathrm{mg} / \mathrm{kg})$.

\section{CONCLUSION}

Covid 19 currently presents a major challenge in human health. To treat this viral infection, different treatments are being tested without getting the real cure so far.

In this present study, we evaluated by In silico test (pathogentherapeutic molecule target modeling) the therapeutic potential of the biomolecules isolated from three Djiboutian medicinal plants, namely Acacia seyal, Cymbopogon commutatus and Indigofera caerulea.

Phenolic compounds give the best preliminary results with minimized docking scores. On the three targeting sites, rutin has better binding energy than the two-drug references Hydroxychloroquine and Remdesivir.

This encouraging result must be confronted with in vitro and in vivo tests to determine the real performance of these biomolecules in the fight against the coronavirus and before clinical trials in humans can be performed.

\section{ACKNOWLEDGMENT}

The authors acknowledge the support of "Laboratoire Lorrain de Chimie Moléculaire L2CM UMR 7053” in Nancy, France.

\section{FUNDING}

Nil

\section{AUTHORS CONTRIBUTIONS}

All the authors have contributed equally.

\section{CONFLICT OF INTERESTS}

Declared none

\section{REFERENCES}

1. Vabret A, Dina J, Brison E, Brouard J, Freymuth F. Coronavirus humains (HCoV). Pathol Biol 2009;57:149-60. 
2. INSERM Lancement d'un essai clinique européen contre le Covid-19. Available from: https://presse.inserm.fr/lancementdun-essai-clinique-europeen-contre-le-covid-19/38737 [Last accessed on 06 May 2020]

3. Walls AC, Park YJ, Tortorici MA, Wall A, McGuire AT, Veesler D. Structure, function, and antigenicity of the SARS-CoV-2 spike glycoprotein. Cell 2020;181:281-92.

4. Dhama K, Sharun K, Tiwari R, Dadar M, Malik YS, Singh KP, et al. COVID-19, an emerging coronavirus infection: advances and prospects in designing and developing vaccines, immunotherapeutics, and therapeutics. Human Vaccines Immunother 2020;1-7. Doi:10.1080/21645515.2020.1735227.

5. Ajibesin KK, Ekpo BA, Bala DN, Essien EE, Adesanya SA. Ethnobotanical survey of Akwa Ibom state of Nigeria. J Ethnopharmacol 2008;115:387-408.

6. Mahmoud Ayan, Nour Ayeh M, Saad O, Camberlin P, Gemenne $\mathrm{F}$, De longueville $\mathrm{F}$, et al. Importance des récentes variations pluviométriques a djibouti et besoins de quantification de leurs impacts. In: Proceedings of the colloques et congrès scientifiques: Communication poster, Djibouti; 2014.

7. Elmi A, Spina R, Abdoul Latif F, Yagi S, Fontanay S, Risler A, et al. Rapid screening for bioactive natural compounds in Indigofera caerulea Rox fruits. Ind Crops Prod 2018;125:12330.

8. Elmi A, Spina R, Risler A, Philippot S, Merito A, Duval RE, et al. Evaluation of antioxidant and antibacterial activities, cytotoxicity of acacia seyal del bark extracts and isolated compounds. Molecules 2020;25:2392.

9. Elmi A. Etudes phytochimiques de plantes médicinales djiboutiennes a effets antimicrobiens et anticancereux. These Nancy; 2018.

10. Fearon D, Powell A, Douangamath A, Owen C. PanDDA analysis of COVID-19 main protease against the DSI-poised Fragment Library. Available from: http://www.rcsb.org/structure/5R84 [Last accessed on 07 May 2020].

11. Dahms SO, Jiao GS, Than ME. Structural studies revealed active site distortions of human furin by a small molecule inhibitor. ACS Chem Biol 2017;12:1211-6.

12. Shang J, Ye G, Shi K, Wan Y, Luo C, Aihara H, et al. Structural basis of receptor recognition by SARS-CoV-2. Nature 2020;581:221-4.

13. Berman HM, Battistuz T, Bhat TN, Bluhm WF, Bourne PE, Burkhardt $\mathrm{K}$, et al. The protein data bank. Acta Crystallogr D Biol Crystallogr 2002;58:899-907.
14. Friesner RA, Banks JL, Murphy RB, Halgren TA, Klicic JJ, Mainz DT, et al. Glide: a new approach for rapid, accurate docking and scoring. 1. Method and assessment of docking accuracy. J Med Chem 2004;47:1739-49.

15. Borrel A, Regad L, Xhaard H, Petitjean M, Camproux AC. PockDrug: a model for predicting pocket druggability that overcomes pocket estimation uncertainties. J Chem Inf Model 2015;55:882-95.

16. Discovery studio life science modeling and simulations; 2008.

17. Daina A, Michielin O, Zoete V. Swiss ADME: a free web tool to evaluate pharmacokinetics, drug-likeness and medicinal chemistry friendliness of small molecules. Sci Rep 2017;7:42717. Doi:10.1038/srep42717.

18. Minovski N, Perdih A, Solmajer T. Combinatorially-generated library of 6-fluoroquinolone analogs as potential novel antitubercular agents: a chemometric and molecular modeling assessment. J Mol Model 2012;18:1735-53.

19. Cheng F, Li W, Zhou Y, Shen J, Wu Z, Liu G, et al. admet SAR: a comprehensive source and free tool for assessment of chemical ADMET properties. J Chem Inf Model 2012;52:3099-105.

20. Rane JS, Chatterjee A, Kumar A, Ray S. Targeting SARS-CoV-2 spike protein of covid-19 with naturally occurring phytochemicals: an in silco study for drug development; 2020.

21. Nguyen TTH, Woo HJ, Kang HK, Nguyen VD, Kim YM, Kim DW, et al. Flavonoid-mediated inhibition of SARS coronavirus 3Clike protease expressed in Pichia pastoris. Biotechnol Lett 2012;34:831-8.

22. Park JY, Yuk HJ, Ryu HW, Lim SH, Kim KS, Park KH, et al. Evaluation of polyphenols from Broussonetia papyrifera as coronavirus protease inhibitors. J Enzyme Inhibition Med Chem 2017;32:504-12.

23. Khaerunnisa S, Kurniawan H, Awaluddin R, Suhartati S, Soetjipto S. Potential inhibitor of covid-19 main protease ( $\left.\mathrm{Mpr}^{\circ}\right)$ from several medicinal plant compounds by molecular docking study. Med Pharmacol 2020. Doi:10.20944/preprints 202003.0226.v1

24. Jo S, Kim S, Shin DH, Kim MS. Inhibition of SARS-CoV 3CL protease by flavonoids. J Enzyme Inhibition Med Chem 2020;35:145-51.

25. Sharma R, Panigrahi P, Suresh CG. In silico analysis of binding site features and substrate selectivity in plant flavonoid-3-0 glycosyltransferases (F3GT) through molecular modeling, docking and dynamics simulation studies. PLoS One 2014;9:e92636. 